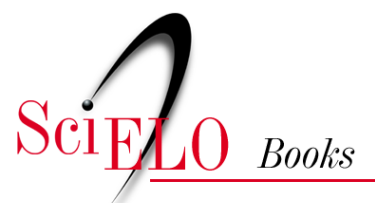

\title{
5. Rua e movimento
}

vivendo em público na eternidade do transitório

\author{
Sarah Escorel
}

\section{SciELO Books / SciELO Livros / SciELO Libros}

ESCOREL, S. Rua e movimento: vivendo em público na eternidade do transitório. In: Vidas ao léu: trajetórias de exclusão social [online]. Rio de Janeiro: Editora FIOCRUZ, 1999, pp. 221-255. ISBN: 978-85-7541-605-1. Available from: doi: 10.7476/9788575416051.0007. Also available in ePUB from: http://books.scielo.org/id/rbtvb/pdf/escorel-9788575416051.pdf.

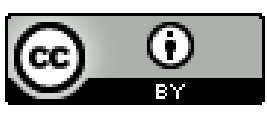

All the contents of this work, except where otherwise noted, is licensed under a Creative Commons Attribution 4.0 International license.

Todo o conteúdo deste trabalho, exceto quando houver ressalva, é publicado sob a licença $\underline{\text { Creative Commons }}$ Atribição 4.0. 


\section{$\underline{5}$ \\ RUA E MOUImEnTO: vivendo em público na eternidade do transitórıo}

Пeste capítulo são analisados os elementos que configuram (e tornam homogênea) a população de rua: o espaço em que habitam e sobrevivem por meio de modalidades que lhes permitem 'satisfazer' suas necessidades vitais, e a principal conseqüência de habitar nesse espaço, ou seja, o movimento contínuo, incessante.

\section{UIUERDO NAS RUAS}

A rotina da sobrevivência nas ruas envolve a resolução das necessidades básicas, categoria que provoca uma série de questionamentos quanto às possibilidades de sua mensuração. No caso da população da rua, o que está sendo assim denominado é o mínimo necessário para manter-se com vida. Essas necessidades devem ser resolvidas de alguma forma, através de uma rotina diária, cujo produto é a possibilidade de sobreviver naquele dia.

A primeira necessidade básica a ser considerada é o teto, o abrigo, por ser a carência primordial que caracteriza a população de rua - aqueles que fazem das ruas a sua moradia. Possibilita também assinalar tipos de população de rua, distinguindo entre aqueles que ficam na rua (circunstancialmente), os que estão na rua (recentemente) e os que são da rua (permanentemente). Tanto os que ficam na rua quanto os que estão nas ruas alternam a via pública com alojamentos, pensões e albergues, e os considerados como sendo da rua moram permanentemente nelas ou em casas abandonadas, eventualmente alojando-se em albergues e pensões (Sebes, 1992).

A escolha do local e sua qualificação em melhor ou pior são feitos levandose em conta a segurança da localidade, o acesso à rede de sobrevivência (e sua opinião sobre ela) e as relações estabelecidas com os transeuntes. Essa escolha, como as demais características da população de rua, é extremamente diversificada, 
variando desde aqueles que transportam a 'cama', isto é, papelões para forrar um canto, até os que procuram recriar um ambiente doméstico, estabelecendo uma subdivisão em 'cômodos' do espaço coletivo.

Em geral, procuram diminuir a visibilidade da ocupação do espaço e, dessa maneira, aumentar sua proteção, tentando passar despercebidos: fazem arranjos com papelões, caixas de papel e caixotes de madeira, construindo espécies de biombos, atrás dos quais se situam, ou acomodam-se perto de lixo ou de entulhos de obras, misturando-se de tal forma com estes que à distância sua presença pode ser imperceptível. Embora essas formas de esconderijos sejam mais freqüentes, encontram-se também muitos que ficam esparramados na via pública, que dormem efetivamente ao léu, sem qualquer proteção (pode-se supor tratar-se de pessoas alcoolizadas), sem nada a separá-los da sujeira da calça$\mathrm{da}$, obrigando os transeuntes a se desviarem para não pisar neles.

Alguns se instalam de maneira tão permanente que um verdadeiro dormitório ao ar livre é criado, como no Largo de São Francisco, no Centro, onde observei um conjunto de 'camas' arrumadas, uma do lado da outra, em cima das quais as mulheres conversavam enquanto as crianças brincavam nos degraus da igreja. $\mathrm{Na}$ praça Serzedelo Corrêa, em Copacabana, observei um grupo que tinha dormido num pedaço da calçada. Escovavam os dentes perto da árvore, urinavam nas grades e 'construíam' paredes móveis (biombos) para trocarem de roupa.

Alguns moradores de rua relatavam dormirem, ocasionalmente ou de forma mais constante, em carros, vagões de trem ou bancos da Rodoviária. Também narravam que quando tinham rendimentos, se hospedavam em pensões baratas e precárias, onde era possível, além do abrigo, usar o banheiro e lavar as roupas. Manuel me falou de um custo de R\$ 7 por noite, na ocasião inacessível para ele, que pedia dinheiro $(\mathrm{R} \$ 1,10)$ para ir de ônibus até a Barra da Tijuca, onde tentaria conseguir algum trabalho. Um jovem em Botafogo mencionou o custo de R\$ 16 para dormir num hotel com a mulher, que estava grávida, e pedia dinheiro, pois naquele dia só tinha conseguido doze reais.

Embora a cidade do Rio de Janeiro não apresente as baixas temperaturas observadas em São Paulo, o frio é um problema para os moradores de rua porque, além de não terem um teto, em geral as vestimentas não protegem o suficiente. Por ocasião do trabalho de campo, em abril (outono), Márcia, Miguel, Cícero e 'Russo' pediam roupas e agasalhos. Na construção de um abrigo que os proteja contra as intempéries são utilizados diversos apetrechos: excetuando-se aqueles que não têm nada, verificamos o uso mais comum de papelões para forrar a calçada, mas também de espuma, colchonetes e até colchões como o de Solange, que era grande, de casal, tipo ortopédico ou, no caso de Rodrigo, que tinha dormido sobre uma porta e amanhecera com o rosto cheio de tinta. 
Cobrem-se com lençóis, colchas e cobertores - estes, em sua maioria, são típicos de doação: de cor cinza e ásperos, utilizados também como 'capas' durante o dia. Os travesseiros improvisados vão desde uma quina da calçada até sacolas e mochilas, o que é também uma forma de proteger os pertences contra roubos. Alguns poucos moradores de rua conseguem improvisar um local com relativo conforto para dormir, mas, em geral, o lugar é apenas um canto para 'encostar o corpo' e cochilar. No caso daqueles que se instalam nas ruas o acúmulo de pertences (sacolas, caixas e caixotes, colchões, apetrechos para cozinhar, criando as 'instalações') aumenta a visibilidade e, portanto, a repressão tanto dos órgãos públicos quanto dos moradores com teto na localidade.

Essa precariedade de abrigo nas ruas deve considerar a vulnerabilidade habitacional ou mesmo a ausência de moradia das classes trabalhadoras pobres. Luiz Augusto referiu ocasiões em que, mesmo empregado na construção civil com carteira assinada, não tinha alojamento e dormia na praia. Uma família composta por casal e três filhos que solicitou ajuda na Comunidade Evangélica de Jesus relatava morar num barraco improvisado debaixo de um viaduto. $\mathrm{E}$ Solange, que dizia ter um quarto em Queimados (Baixada Fluminense) mas que não tinha quintal e chovia dentro.

Além daqueles que vivem nas calçadas, muitos moradores de rua se apossam de casas abandonadas e deterioradas ('mocós') que o transeunte não percebe que estão habitadas. A 'arquitetura da indigência' ${ }^{257}$ envolve criatividade na utilização do material disponível no lixo: André, catador da rua Sorocaba, dorme na marquise do depósito de ferro-velho e, quando chove, faz uma 'meiaágua' construída com papelão e plástico para protegê-lo. ${ }^{258}$ Ele me diz que poderia pagar alojamento, mas não compensa porque ele trabalha até duas horas da manhã, horário em que já não pode mais entrar, e se dormisse de dia não teria dinheiro para pagar o alojamento. Considerava, portanto, o alojamento um gasto desnecessário. A variedade de 'habitações' inclui, além dessas, buracos cavados ou já existentes sob viadutos e pontes, bancos de praças não cercadas, árvores, carrinhos de sucata, banquinhas de mercadorias e cabines de ban$\cos 24$ horas ou telefônicas.

A comida é a necessidade básica a que os moradores de rua têm mais acesso e cuja satisfação os faz comparar favoravelmente a situação de desabrigo frente às condições anteriores. "Fome não é problema" e "comida não falta" são comentários feitos com freqüência. Dedilei, morador de rua que já estivera

257 "Miseráveis criam arquitetura da indigência exercendo a macabra criatividade a que a miséria obriga. Entre o conforto mínimo de um barraco de papelão e madeira e o mais absoluto desabrigo (...) esse povo inventou suas próprias alternativas". O Estado de S. Paulo, 30/mar./92, texto de Marcos Emílio Gomes.

Diário de campo, Botafogo, segunda-feira, 3/3/97. 
em um centro de recuperação vinculado à Comunidade Evangélica de Jesus, relatava que lá davam pouca comida e que esta, muitas vezes, era apenas mingau de aipim, o que, pelo seu jeito de falar, lhe era muito desagradável. Quando Wanda retrucou, perguntando se ele preferia comer a comida 'de porco' que ele comia na rua, Dedilei nem pestanejou e respondeu: "na rua eu como do bom e do melhor". ${ }^{259}$

Numa freqüência muito menor alguns moradores referiram passar fome na rua, como Manuel, que me disse estar com dor de cabeça e com muita fome, pois não comera nada durante o dia, enquanto procurava emprego. André me relatou já ter passado fome mas não na rua e nesta, trabalhando como catador, não precisava freqüentar as instituições que distribuem comida. Dalton também mencionou ter passado fome, mas dizia que não passava mais: comia nos bares pagando sua própria comida e de vez em quando ganhava comida em troca da retirada de papelão e entulho. Cícero passou fome quando 'caiu na rua' (Aterro do Flamengo) e não conhecia nada. Por outro lado, famílias abrigadas, embora precariamente, passavam fome, como a que compareceu na Comunidade Evangélica de Jesus pedindo comida, pois não tinham nada para comer em casa, 'só um pouco de sal'.

Apenas numa ocasião presenciei o fato de que a quantidade de alimentação distribuída foi menor do que a demanda; em geral, tanto a observação quanto as referências dos próprios moradores de rua foram de excesso de doações de comida. Solange me dizia que "sobra de jogar fora". André relatava que às vezes passava um motorista de táxi e, mesmo vendo que eles estavam fazendo comida, dava quentinhas para eles. Miguel dizia que no centro da cidade era só ficar debaixo de uma marquise que "recebe comida, recebe roupa (...) no Centro a pessoa é até acordada para tomar café". ${ }^{260}$

Os moradores de rua enfatizavam e valorizavam seu grau de autonomia quando podiam comprar a alimentação em lanchonetes ou pensões (quentinha, sanduíche) em contraposição à situação dos que dependiam das entidades religiosas e caritativas que distribuem alimentação. Além da utilização dessa 'rede de sobrevivência', alguns moradores de rua recolhiam a xepa das feiras ou pediam aos feirantes, embora esse mecanismo fosse evitado pelo risco de encontrar conhecidos. Presenciei a compra de alimentos em supermercados e o cozinhar nas ruas, ainda que esta atividade dependesse de hora e local convenientes, assim como da obtenção de água e disponibilidade de apetrechos. Os fogões eram improvisados sobre tijolos, restos de madeira, raramente carvão, aproveitando-se o que se encontrava no lixo ou fabricando utensílios. A garrafa plásti-

\footnotetext{
259 Diário de campo, Comunidade Evangélica de Jesus, quinta-feira, 16/11/95.

260

Diário de campo; Botafogo, quarta-feira, 9/4/97.
} 
ca de água mineral ou de refrigerante cortada tornava-se um recipiente para tomar sopa. As ruas limitam o que é possível cozinhar à denominada 'comida de latão' pois a panela é um galão de tinta onde os alimentos são cozidos todos misturados. Nas ruas também o parâmetro de referência sobre a pobreza é a comida: em relação às atividades exercidas comentavam que "mal dá" ou "só dá" para comprar comida.

A alimentação pode ser obtida através de entidades assistenciais que se 'especializam' em determinadas refeições e estabelecem horários fixos de distribuição: nos Pequeninos de Jesus é distribuído apenas o café da manhã (que, numa ocasião, foram 170), só para os homens, em dias da semana; no Dispensário de Pobres Imaculada Conceição (Irmã Zoé) é ofertada uma sopa no almoço (por volta das 11 horas da manhã); o grupo do "seu" Paulo distribui pão e sopa na hora do jantar nos dias de semana em Copacabana e o Batalhão da Polícia Militar da São Clemente (Botafogo) oferece, quando sobram, os restos das refeições também em dias de semana. Raramente há distribuição de comida pelas entidades assistenciais nos fins-de-semana. Ocasionalmente, algumas padarias e lanchonetes distribuem pães e salgados que sobraram do dia anterior. De qualquer maneira, há uma submissão aos horários e normas dos doadores, assim como à qualidade da comida, que é freqüentemente classificada como baixa: a sopa da Irmã Zoé não é considerada boa ("é lavagem", diz Chicão); já a sopa do "seu" Paulo é gostosa, consistente ("é abençoada", diz Manuel).

$\mathrm{Na}$ Fazenda Modelo, segundo os depoimentos, a qualidade da comida é muito ruim: o café "parece água suja, é cevada" e "dão num copo plástico, todo gorduroso, todo sujo, com pão duro". O valor nutricional das refeições é precário, ainda mais considerando-se o desgaste físico da movimentação contínua dos moradores de rua. Devem ser consideradas as dificuldades das entidades em cozinhar grandes quantidades de comida (daí, a tendência à sopa) assim como em obter os alimentos em quantidade e qualidade adequados: no caso do grupo de "seu" Paulo, a distribuição dependia da contribuição do supermercado próximo ou daquilo que conseguiam comprar a partir de doações dos fiéis da Igreja Católica da Renovação Carismática de Copacabana específicas para o desenvolvimento daquela atividade.

Recebendo como doação é difícil poder escolher o que se gosta de comer, tendo que se submeter ao que se é oferecido. E, nesses casos, há que se levar em conta a inadequação de certas doações, como foi o caso da lata de leite em pó comprada para Natália (uma criança de cerca um ano) que a mãe (Vanda) passou adiante dizendo que para fazer o leite precisaria conseguir água e uma maneira de esquentá-la.

Alguns moradores de rua referiram doações particulares a partir de relacionamentos interpessoais, isto é, locais que só davam comida para alguns pou- 
cos conhecidos ou para determinadas faixas etárias. Rodrigo, de 13 anos, dizia ganhar comida de uma lanchonete, e Miguel e Cícero pegavam comida numa pensão e num colégio que só davam para alguns 'cadastrados'.

Feita a distribuição na via pública, os moradores de rua escolhem um lugar qualquer e comem 'feito bicho', agachados no chão. Miguel, que passara um tempo na casa de um amigo em Nova Iguaçu, contava que a temporada tinha sido boa porque já tinha até esquecido como era "essa coisa de sentar na mesa para comer, essas coisas de família" e dizia que um conhecido seu, mesmo com dinheiro, não conseguia mais sentar num restaurante para almoçar, dava a vasilha ao garçom e ia comer fora do local. ${ }^{261}$

Água e esgoto são carências de parcela significativa da população pobre da cidade do Rio de Janeiro, principalmente em áreas periféricas, ${ }^{262}$ e são praticamente inexistentes como equipamentos públicos oferecidos à população em geral no seu transitar pelo espaço urbano. Essa é a necessidade básica da população de rua com menores possibilidades de provimento e gera a sujeira que muitas vezes é considerada como parte de sua 'natureza'.

A higiene corporal é realizada utilizando a água disponível em laguinhos', fontes e chafarizes nas praças públicas. Foi mencionada a obtenção de água em obras, canos furados da Cedae, casas abandonadas e "uma manilha de água doce na praia de Botafogo de onde sai água clarinha que dá para tomar banho, mas pra beber não presta"263. Essas informações são rapidamente compartilhadas, gerando aglutinação de moradores de rua, o que desencadeia o conserto por parte da companhia de água e esgoto e, novamente, a carência de água para a higiene.

Solange tomava banho num 'esguicho' na Praia de Botafogo, dizia que o "moço que trabalha na obra empresta". André e Chicão tomavam banho no depósito da rua Sorocaba, onde também pegavam água para cozinhar na calçada. Miguel e Cícero relatavam tomar banho no cemitério. O mar é acessível e utilizado algumas vezes, mas não é considerado como apropriado para banho, pois o corpo fica salgado. Marcelo dizia tomar banho na igreja Santa Margarida Maria (seu 'ponto' de guardar carros, e onde já dormiu) ou senão na Comlurb. Observa-se a tentativa de manter-se limpo, o que nem sempre é possível mesmo quando se consegue tomar banho, pois é necessário também ter roupa limpa para trocar.

A lavagem de roupas também é feita em público, sendo comum a visão de varais construídos com barbantes esticados entre pilotis ou as roupas secando

261 Diário de campo, Botafogo, quarta-feira, 2/4/97.

262 Ver acesso à rede geral de água e de esgoto sanitário em 1990 na Região Metropolitana do Rio de Janeiro em Rocha, 1995.

263 Diário de campo, Botafogo, Luiz Augusto, quinta-feira, 20/3/97. 
sobre os blocos de cimento que impedem o estacionamento dos carros nas calçadas, ou ainda nas grades e por cima dos bancos das praças. Manuel me dizia estar cheio de roupa para lavar, mas que não tinha onde fazê-lo. Já André dizia lavar a roupa na lavanderia, o que não quer dizer que pagasse pelo serviço.

Foram observadas pessoas que, morando na rua, não se descuidavam da limpeza do local, varrendo as calçadas com vassouras improvisadas, e tampouco da toalete matinal: escovando os dentes, passando desodorante, trocando a roupa (tirando o 'pijama'), penteando os cabelos, observando-se nos espelhos laterais dos carros estacionados. Além da limpeza pessoal, foi possível observar certos traços de vaidade numa arrumação cuidadosa das vestimentas, nos cabelos pintados e nas unhas com esmalte.

O cuidado com a aparência inclui cortar o cabelo e fazer a barba. Manuel conseguira um barbeador descartável nos Pequeninos de Jesus, mas estava procurando um banheiro para fazer a barba, ficar com uma boa aparência e procurar emprego. O corte de cabelo é realizado por membros do grupo do "seu" Paulo, em plena via pública, ou no caso da Comunidade Evangélica de Jesus, na própria sede, em alguns domingos. Não é possível escolher um estilo de corte, limitando-se a oferta assistencial a raspar a cabeça (ou quase, no caso das mulheres). Essa imposição estética tem um sentido prático, na medida em que é mais fácil de lavar e demora mais a precisar voltar a cortar, porém homogeneiza a aparência dos moradores de rua, que apresentam um 'biótipo' tanto na sujeira quanto na limpeza.

Em geral a aparência dos moradores de rua revela que a higiene é extremamente precária ou ausente. Pode ser realizada em locais públicos com água ou, na dependência da boa vontade dos proprietários, em locais fixos que limitam a clientela. Nesse sentido foram mencionados um estabelecimento de saúde, postos de gasolina, bares e lanchonetes.

Poucas entidades assistenciais oferecem a possibilidade de tomar banho, e ainda assim uma oferta limitada, como na Comunidade Evangélica de Jesus, onde era possível tomar banho apenas nos domingos e tinha que ser rápido. $\mathrm{O}$ mais freqüente é ficar vários dias sem tomar banho e, com o passar do tempo, diante das dificuldades, não se aborrecer com a própria sujeira. Alexandre dizia que estava há cinco dias sem tomar banho mas, levantando a camisa e mostrando o corpo, afirmava: " até que não tô muito sujo, não é?, dá para agüentar mais uns três dias." ${ }^{264}$ Vanda utilizou uma folha de caderno para limpar Natália, que evacuara, amassou o papel, jogou-o fora ali mesmo na calçada e voltou a vestila com a mesma calça. Cícero afirmava:

264 Diário de campo, Botafogo, quarta-feira, 9/4/97. 
A bigiene pessoal é a pior coisa que existe na rua. Não dá pra você se manter limpo porque o máximo que você vai fazer é você dormir limpo e acordar sujo. Você já acorda sujo, tá entendendo? porque dormiu na rua, porque dormiu em papelão, porque dormiu em jornal, dormiu no chão".265

A rua por si é suja, a limpeza pública limita-se a varrer os locais e retirar os sacos de lixo. Raramente as ruas são lavadas e a presença de ratos e baratas é constante. Assim, por mais que os moradores de rua se esforcem em manter o asseio pessoal, dificilmente conseguem ficar limpos.

O vestuário é também geralmente obtido por meio de doações. Mais raramente é comprado, como fazia Miguel, que mencionava esse item de gasto e conhecia as lojas onde era possível comprar mais barato, fazendo comparações de preços entre as mesmas lojas localizadas na Zona Sul e nos subúrbios. A dificuldade é que nem sempre as ofertas de vestuário são adequadas para o potencial usuário das mesmas. Algumas entidades só oferecem roupas de adultos e as crianças de rua em geral vestem roupas muito maiores que o seu tamanho. Chicão nos mostrou um monte de roupas que ganharam e dizia que daquilo tudo só prestavam duas calças jeans que estavam em bom estado; o resto não prestava. Além do mais, ele não gosta de jeans, gosta de roupa mais leve, de tergal.

As doações não atendem às necessidades ou preferências de quem recebe, configurando muitas vezes uma forma de os doadores livrarem-se de roupa velha. Guto, que pedira um calçado nos Pequeninos de Jesus, recebera um tênis que, segundo Miguel, era "melhor jogar no lixo". Miguel declarava que "eles só dão as piores coisas que tem ali, é umas roupas tudo remendadas"; que o que recebem em bom estado revendem num bazar. Já Rodrigo parecia satisfeito com as roupas que ganhara de uma moça, dizendo que eram melhores que as que tinha em casa. A oferta de roupas velhas parece ser suficientemente grande para que os moradores de rua as considerem descartáveis e se poupem do trabalho de lavá-las. As roupas consideradas 'boas', além de relativamente novas, devem ter algumas características: serem fáceis de lavar, secarem rápido e não serem muito pesadas para carregar. A maior dificuldade é o calçado, tanto em obter o número adequado como em preservá-lo, sendo objeto de cobiça de outros moradores de rua e o primeiro objeto a ser roubado.

A segurança é um aspecto fundamental na escolha do local de moradia. Num primeiro momento, segurança e cobertura são os principais requisitos.

265 Diário de campo, Copacabana, Cícero, quinta-feira, 17/4/97. 
Em seguida, para sobreviver na rua, os locais são escolhidos segundo as possibilidades de oferta de água, ${ }^{266}$ alimentos e/ou doações e rendimentos.

É difícil dormir na rua: é preciso dormir 'com um olho fechado e outro aberto', em local iluminado, em grupos ou em áreas comerciais que dispõem de vigilantes noturnos que não se incomodem com a presença dos moradores de rua. O sono não é reparador. É necessário encontrar um abrigo contra a chuva e o frio, mas também seguro contra as violências institucionais (órgãos públicos de assistência social, polícia, fiscais municipais de habitação) e contra roubos e agressões entre os moradores de rua. Em geral, a noite é utilizada para as atividades sociais, como comer e beber, ou para realizar o trabalho de coleta de lixo, dormindo de dia quando se sentem mais seguros. Quando dormem de noite, procuram locais de baixa visibilidade, como em cima de bancas de jornais ou das guaritas de ônibus, ou senão de alta visibilidade para que possam contar com uma eventual solidariedade dos transeuntes. Sob o aspecto da segurança encontram-se também as dificuldades de acumular pertences ou mesmo mercadorias para revenda, pois não apenas denunciam a condição de morar nas ruas, aumentando a possibilidade de repressão, como instigam a inveja de outros moradores de rua, que agridem aquele que tem alguma coisa para roubá-lo. Daí quase sempre selecionarem o que recebem como doações segundo não apenas a necessidade, mas também o peso e o volume a ser transportado.

\section{Rede de sobreviuêncıa}

A rede assistencial é, sem dúvida, parte crucial da 'mágica' da sobrevivência dos moradores de rua. Composta por uma maioria de entidades privadas religiosas, as instituições trabalham com essa população distribuindo alimentação, roupas, assistência social - como auxílio na obtenção de documentos - e, mais raramente, assistência médica. As entidades não trabalham de maneira integrada e a articulação entre elas (a 'rede') é realizada pela própria população de rua, cujo conhecimento das atividades oferecidas lhes permite construir um roteiro diário de demandas, que incide tanto em sua territorialização quanto na sua distribuição de tempo. As entidades podem funcionar como elementos catalisadores da formação de vínculos, solidariedade e agregação da população de rua, tanto com as entidades quanto entre os moradores.

As informações relativas à rede de sobrevivência são compartilhadas entre os moradores de rua - ao contrário de outras informações relativas aos locais e

266 A pequena disponibilidade de água potável, assim como as dificuldades de obtenção de doações entre os transeuntes do Aterro do Flamengo, são explicações possíveis para a relativamente baixa densidade da população de rua nesse vasto espaço público carioca. 
atividades de obtenção de rendimentos ou mesmo de benefícios alimentares de melhor qualidade - e vários relatos reiteraram que depois de um tempo na rua aprenderam onde distribuíam comida. Miguel me forneceu um roteiro abrangente de distribuição, com concentração na Zona Sul - mas que englobava o centro da cidade e bairros dos subúrbios -, assinalando os dias, o horário e o tipo de comida distribuída. O roteiro revelava uma topografia da distribuição de comida que interfere na topografia e na tipologia dos grupos que habitam os diversos espaços públicos da cidade. Miguel afirmava que a pessoa pode viver na rua sem fazer nada, só seguindo o roteiro de distribuição de comida. Cícero considerava que aqueles que agiam dessa forma eram "doentes por comida, sabia? Não é que ele precisa, tem a gula, anda o Rio de Janeiro completo" 267 .

A peregrinação por locais que distribuem comida, além de suprir necessidades alimentares, é uma modalidade de estabelecimento de vínculos sociais entre pessoas que compartilham uma mesma condição discriminada e estigmatizada. A ânsia de uma alimentação contínua, a 'gula' a que se refere Cícero, pode ser uma forma de preencher o tempo, assim como a tentativa de suprir uma carência em potencial, isto é, sabe-se que fora daqueles horários não haverá condições de se obter uma refeição.

Ainda que as entidades assistenciais de caráter religioso priorizem os vínculos espirituais e acentuem que nestes se encontram as sementes das possibilidades de recuperação individual e reintegração social, a população de rua transita por diversas orientações religiosas, estabelecendo vínculos de caráter instrumental e material, ou seja, aceita as preleções para poder obter os auxílios em espécie que lhe serão posteriormente ofertados. A gama de atividades oferecidas está geralmente restrita à oferta de alimentação e esta se resume apenas a uma refeição em dias de semana. ${ }^{268}$ Não encontramos qualquer atividade que estivesse vinculada com a obtenção de trabalho e rendimentos. A limitação da oferta assistencial foi criticada por Cícero:

ó só, a pessoa dá comida a outra pessoa, é uma coisa que a pessoa sempre vai necessitar (...) boje você me dá essa comida aqui, mas quando for amanhã no mesmo borário eu vou precisar comer de novo (...). Você viu o que eu falei pra Adi: 'Adi, ajudar uma pessoa não é dar comida não, é dar um trabalbo, tá entendendo?', é ver que a pessoa melhorou, de alguma forma, né?, não é, eu vim aqui, dar café, dar isso e aquilo, e como é que eles ficam felizes de ver a pessoa sempre na pior, pegando comida e eles dando comida? $?^{269}$

\footnotetext{
267 Diário de campo, segunda-feira, 14/4/97.

268 Nos Pequeninos de Jesus, em particular, existe a oferta inovadora da atividade de arteterapia.

Diário de campo, Botafogo, segunda-feira, 14/4/97.
} 
Além de a oferta ser limitada, as entidades estabelecem normas de conduta e parâmetros de comportamento para a manutenção da atividade. Em geral, um membro da equipe assistencial de biótipo específico - homem, alto e musculoso funciona como segurança e estabelece um controle atento do desenvolvimento da atividade. No Batalhão da Polícia Militar da rua São Clemente, segundo Luiz Augusto, "não pode chegar chapadão, (eles) não gostam de bagunça". O não cumprimento das normas pode levar à suspensão das atividades, como ocorreu na igreja Metodista do Bairro Peixoto (Copacabana). ${ }^{270}$ Miguel mencionou que uma igreja evangélica de Ipanema distribuía almoço, além de possibilitar fazer a barba e cortar o cabelo, mas "fizeram muita bagunça, dava muita confusão" e agora só distribuíam almoços aos domingos. No Dispensário da Irmã Zoé ocorreram vários episódios em que a população de rua destruiu ou incendiou o refeitório e o galpão onde aguarda a hora de distribuição da sopa, levando à interrupção temporária da atividade. Afora a suspensão das atividades por esses motivos, foi verificada também, em algumas entidades, a interrupção e a irregularidade da assistência oferecida.

Assim, a rede de entidades assistenciais participa da 'mágica' da sobrevivência dos moradores de rua, embora alguns locais selecionem seus 'clientes', constituindo doações particulares. Mesmo quando não há discriminação dos demandantes, as doações são normatizadas com exigências de padrões de comportamento, valorização do vínculo espiritual e, como me foi relatado assim como observado, há uma humilhação (um 'sermão') como contraparte da doação. Como dizia Miguel: " não é a mesma coisa, sabia?, tu ir e agarrar, sentar-se num lugar e tu comprar tua própria comida, que os povos que dá as coisas; lá tu tem que ficar escutando piadinha, tem que ficar escutando negocinho."271

\section{O privado em público}

A sobrevivência cotidiana dos moradores de rua, as atividades do labor, são realizadas em público, transgredindo os princípios básicos da organização social, que distinguem claramente as esferas e as atividades públicas das privadas, ou, nos dizeres de Da Matta, o que é próprio da 'casa' e o que é próprio da 'rua'. Esse deslocamento de ações e papéis sociais é percebido como um desvio

270 O trabalho com a população de rua foi iniciado com a distribuição de refeições aos domingos à noite, $\mathrm{e}$ foi sendo paulatinamente ampliado com a distribuição de jantar às quartas-feiras, às terças-feiras e, posteriormente, com a distribuição também de almoços às terças e quintas-feiras. Os pedintes eram recebidos no interior da igreja, tomavam banho, recebiam comida e 'a palavra'. A demanda foi crescendo e, quando eram cerca de oitenta pessoas, começaram a ocorrer problemas de espaço físico, de algazarra e confusão. O local foi assaltado em duas ocasiões e, em função da grande quantidade de pessoas, de brigas, facadas e dos assaltos, decidiram interromper a atividade. Diário de campo, Copacabana, quinta-feira, 20/2/97.

Diário de campo, Botafogo, segunda-feira, 14/4/97. 
e sancionado como tal, com conseqüências na experiência e na identidade social dos moradores de rua.

Arendt analisa as condições de existência humana, as atividades da condição humana e os espaços em que estas se realizam, tendo como ponto de partida de sua matriz teórica a polis grega. ${ }^{272}$ As condições de existência humana são a própria vida (natalidade e mortalidade), a pluralidade, o mundanismo e a terra. A vida corresponde ao labor; o mundanismo refere-se à atividade do trabalho ou fabricação e a pluralidade é a condição que corresponde à ação.

A esfera privada corresponde à família, às atividades regidas pelas necessidades relacionadas com a sobrevivência individual e da espécie. É a esfera da casa, do que é próprio de cada um. Arendt nos relembra a acepção original do termo privado: ser destituído de coisas essenciais à vida como também da própria realidade, de uma relação com os outros através de um mundo comum, e de realizar algo mais permanente que a própria vida. A dor, o sentimento mais intenso que conhecemos, é ao mesmo tempo o mais privado e o menos comunicável de todos. É uma experiência limítrofe entre a vida, no sentido de 'estar na companhia dos homens', e a morte. Assim o privado envolve também aquilo que é oculto (está escondido) e é indizível (não pode ser expresso em palavras).

Um elemento fundamental da esfera privada é a propriedade, no sentido de 'ter seu lugar no mundo'. Para a autora a interpretação moderna que equaciona propriedade e riqueza distorce o sentido original do termo, pois na antigüidade possuir uma propriedade privada possibilitava a plena participação na esfera pública. Escravos e estrangeiros podiam ser ricos (ter posses) mas não tinham um lugar próprio nem a cidadania dele decorrente. ${ }^{273}$ A propriedade no sentido arendtiano (ou helênico) está relacionada com cidadania, igualdade, proteção das leis e segurança. Ser político significava atingir a mais alta possibilidade da existência humana; mas não possuir um lugar próprio e privado significava deixar de ser humano.

Assim, o espaço privado significa ao mesmo tempo aquilo que lhe é próprio (um lugar no mundo) e o que deve ser ocultado, sendo representado, desde a antigüidade até os dias de hoje, pela parte corporal da existência humana, isto é, pelo labor. Para a autora, o exercício da liberdade é precedido pelo ato de libertação das necessidades materiais da vida. Dispondo de sua privatividade, não estando à disposição de um amo (ao contrário do escravo) e não sendo forçado pela pobreza, o indivíduo podia ingressar na vida pública: “a liberdade só é possível depois de atendidas as necessidades muito mais urgentes da própria existência, cujo meio de atendimento é o labor". Após dominar as próprias

272 Todas as referências são de Arendt (1991).

273 "A riqueza, não importa quantas vidas individuais ela possa suprir, não deixa de ser algo destinado ao uso e ao consumo"; (...) "a riqueza comum jamais pode tornar-se comum no sentido que atribuímos ao mundo comum, permanecendo estritamente privada" (Arendt, 1991). 
necessidades vitais, o indivíduo está potencialmente livre para transcender sua própria existência e ingressar no mundo comum a todos. Mas o estado de liberdade não se seguia automaticamente ao ato de liberação. A liberdade necessitava da companhia de outros homens e de um espaço público comum para encontrá-los - um mundo politicamente organizado.

Arendt define 'público' através de dois fenômenos correlatos mas não idênticos: o que pode ser visto e ouvido por todos e tem a maior divulgação possível (publicidade), e aquilo que é comum a todos e diferente do lugar que cabe a cada um dentro dele, o mundo comum. A esfera pública é regida pela igualdade e liberdade dos participantes. Nesse espaço a liberdade constitui uma realidade concreta, o seu exercício pelos homens se dá pelo agir em comum, na construção de um mundo em comum. A ação é a política, a construção é a organização político-social, o homem que age é o cidadão e ao ingressar na esfera pública o indivíduo recebia uma (espécie de) segunda vida, um bios politikos, um modo político de vida. A organização política é diretamente oposta à associação natural, cujo centro é constituído pela casa e pela família. Há uma grande diferença entre aquilo que lhes é próprio e aquilo que lhes é comum.

A esfera pública constitui o espaço de formação de vínculos entre os homens; funciona como

uma mesa (que) se interpõe entre os que se assentam ao seu redor, pois como todo intermediário, o mundo ao mesmo tempo separa e estabelece uma relação entre os homens; enquanto mundo comum, reúne-nos na companhia uns dos outros e contudo evita que colidamos uns com os outros.

É a esfera pública que possibilita a permanência, a imortalidade (no espaço público as coisas são poupadas da destruição pelo tempo) e a transcendência das ações dos homens (ultrapassa a duração de vida dos homens tanto no passado quanto no presente - preexistia e sobreviverá). "É o caráter público da esfera pública que é capaz de absorver e dar brilho através dos séculos a tudo que os homens venham a preservar da ruína natural do tempo". A desgraça da escravidão, segundo a autora, era que, além de não ser livre, o indivíduo era privado de visibilidade (permanecia na obscuridade) e, com isso, "morria sem deixar vestígio algum de ter existido".

$\mathrm{Na}$ tipologia axiológica de Arendt o espaço público é onde se exercita a liberdade, a potencialidade máxima da condição humana. No entanto, essa ação depende da existência da esfera privada. É a coexistência dos espaços que potencializa a ambos. ${ }^{274}$

274 "O extraordinário senso político do povo romano (...) jamais sacrificou o privado em benefício do público mas, ao contrário, compreendeu que estas duas esferas somente podiam subsistir sob a forma de coexistência" (Arendt, 1991). 
Viver uma vida inteiramente privada, como ocorre nas tiranias e nas sociedades de massas, significa que os homens são privados "de ouvir e ver, de serem vistos e ouvidos" e assim restam "prisioneiros da subjetividade de sua própria existência singular que continua a ser singular ainda que a mesma experiência possa ser multiplicada inúmeras vezes: a singularidade multiplicada não se torna mundo comum". Por outro lado, segundo a autora, uma existência vivida inteiramente em público, na presença de outros, torna-se superficial: "retém a sua visibilidade, mas perde a qualidade de vir à tona a partir de um terreno mais sombrio que deve permanecer oculto para não perder sua profundidade".

Mesmo que se possa questionar, após alguns séculos de civilização, a transposição para a era moderna de conceitos e categorias tão bem delimitados na antigüidade, que caracterizavam o indivíduo que não participava do espaço público (da política) como alguém que deixava de ser verdadeiramente humano, não pode ser ignorada (e não foi ultrapassada) a análise de que a existência realizada de forma inteiramente privatizada (no seu metabolismo e na sua própria subjetividade) não deixa vestígios de sua passagem pela Terra.

Tomando as categorias analisadas por Arendt, podemos considerar através do fenômeno da população de rua a transposição para o espaço coletivo de uma atividade (a sobrevivência física, o labor) que, mesmo com as transformações ocorridas na era moderna, sempre permaneceu como sendo do domínio privado. Porém, ao ser exercida em público e assim sendo visível e audível por todos, não deixa de ser uma existência inteiramente privatizada, prisioneiras que essas pessoas estão dos próprios metabolismo e subjetividade. A população de rua não ocupa a esfera pública, não participa da construção de um mundo em comum. E a 'liberdade' de que por vezes afirmam usufruir (em relação a patrões, horários e rotinas) não consegue mascarar que sequer se libertaram das necessidades vitais. Assim, podemos caracterizá-los como indivíduos cuja existência vivida inteiramente em público é integralmente privatizada; uma experiência de vida sem um lugar que lhe seja próprio (nem nas ruas nem fora delas). Essas pessoas exercem o labor no espaço coletivo, mas não participam da esfera pública, aprisionadas no incessante círculo da sobrevivência.

Partindo de outra matriz teórica, Da Matta ${ }^{275}$ afirma que 'casa' e 'rua' constituem uma oposição básica na gramática social brasileira. Oposição complementar, segundo o autor, que permite identificar dois códigos sociais que se reproduzem mutuamente e que estabelecem para cada espaço papéis sociais, objetos e ações que lhe são próprios assim como temporalidades específicas. Diz o autor: "não dormimos na rua, não fazemos amor nas varandas, não faze-

275 O texto básico do autor sobre o assunto é "Carnavais, malandros e heróis: para uma sociologia do dilema brasileiro" (edição consultada, 1990) complementado por outros trabalhos $(1991 ; 1993)$. 
mos refeições com comensais desconhecidos, não ficamos nus em público, não rezamos fora das igrejas...".

A realização de atividades fora de seu domínio específico provoca grave confusão ou até mesmo conflito. (...) Sabemos e aprendemos muito cedo que certas coisas só podem ser feitas em casa e, mesmo quando em casa, dentro de alguns dos seus espaços. (...) A reação ao 'inusitado' é sinal marcante de que temos dentro da própria casa uma rigorosa gramática de espaços e, naturalmente, de ações e reações.

Dessa forma as atividades realizadas fora de seus espaços normais sofrem um 'processo de deslocamento'.

No domínio da 'casa', o código fundamenta-se nas relações pessoais, estabelecidas por laços familiares, de lealdade e de alta intensidade emocional. A categoria 'pessoa' que integra esse domínio é caracterizada pelo autor como presa à totalidade social, complementar aos outros, não tendo escolhas próprias, pois a totalidade tem precedência, e recebendo as regras do mundo onde vive. O tempo na 'casa' tem duração cíclica, como o da vida, o da reprodução biológica, o tempo da natureza. Neste âmbito verifi- ca-se a vertente relacional (que tudo inclui) e hierarquizante (cada qual no seu lugar) de nossa constelação de valores. $O$ universo da casa é próprio para todos os modos de obter satisfação ou alívio fisiológico, para todas as ações relacionadas com o uso, cuidado e recuperação do corpo, isto é, tudo aquilo que Arendt denomina labor.

No domínio da 'rua' prepondera o indivíduo, o idioma da lei universal e da burocracia impessoal. O tempo na 'rua' é um tempo linear, tem duração cumulativa, é o tempo histórico. Para o autor, a rua é equivalente à categoria 'mato' ou 'floresta' do mundo rural, ou seja, um domínio semidesconhecido e semicontrolado, povoado de personagens perigosos. A categoria 'rua' exprime tanto um local particular quanto um domínio complexo. As expressões 'moleque de rua' ou 'já para a rua' são poderosas e ofensivas, designando, num caso, alguém sem orientação moral, e no outro, um modo contundente de eliminar alguém de um ambiente preciso. $O$ indivíduo é caracterizado como livre, com direito a um espaço próprio, igual a todos os outros, com escolhas e consciência individual, e fazendo as regras do mundo onde vive. Esta individualização extremada, em que as referências de sua história familiar e trajetória relacional são perdidas ou não consideradas, é expressa no sentimento de que nada é pior que passar mal ou, ainda, que morrer fora e longe de casa, 'no meio da rua', como um mero indigente - gente que não tem 'onde cair morto'. A individualização também é verificada em estados sociais altamente liminares como a boêmia, o carnaval e a pré-criminalidade, em que 'ninguém conhece ninguém' ou 'ninguém é de ninguém'. 
Numa abordagem que lhe é própria, Da Matta reitera as principais diferenças entre as esferas pública e privada tal como assinaladas por Arendt. Também como a autora, ele enfatiza a complementaridade dos espaços, destacando que se ambos têm um código que the é próprio e específico, eles não estão separados, e mantêm entre si uma relação complexa através de subespaços (praças, mercados, janelas e varandas) e também através de ocasiões especiais (festas), em que a comunicação é possível, obrigatória ou desejável. Além destes ambientes que estabelecem um intercâmbio permanente ou ocasional entre os domínios, $\mathrm{Da}$ Matta aponta para o que denomina "espaços transitórios e problemáticos":

tudo o que está relacionado ao paradoxo, ao conflito ou à contradição como as regiões pobres ou de meretrício - ficam num espaço singular. Geralmente são regiões periféricas ou escondidas por tapumes. Jamais são concebidas como espaços permanentes (...) são sempre vistos como locais de transição: 'zonas', 'brejos', 'mangues' e alagados. Locais liminares, onde a presença da lama marca um espaço físico confuso e ambíguo.

Da Matta assinala que a ocupação da rua como espaço de moradia, isto é, como 'casa', significa uma "subversão de tal ordem que a ocupação define o ocupante". Sendo a rua local de indesejável individualização, luta e malandragem, os que ali vivem 'como se estivessem em casa' são os malandros, os meliantes, os pilantras e os marginais em geral - ainda que esses mesmos personagens em casa possam ser seres humanos decentes e até mesmo bons pais de família:

Podemos assim caracterizar os moradores de rua como seres extremamente individualizados, isto é, cujas trajetórias pessoais e relações afetivas e familiares não são levadas em consideração e aos quais caberia apenas a fria letra da lei. Porém, isso não significa que possam ser caracterizados como 'indivíduos', na medida em que não escolhem nem fazem as regras do mundo em que vivem. Realizando em público todas as ações cujo espaço próprio não é só o da casa mas de cômodos no seu interior, são seres humanos que sofrem um 'processo de deslocamento', ou seja, 'estão fora de lugar'. Como integrantes do mundo da rua, são seres liminares, ocupam um espaço singular que lhes confere as características do próprio espaço: sujo e perigoso. Espaço singular, porém não próprio; e, portanto, transitório. Estão fora da gramática social e para evitar a reação, a confusão e o conflito desencadeados por sua ação de ocupar subversivamente a rua para dela fazer a casa, devem deslocar-se continuamente.

A abordagem interacionista do desvio é um bom instrumental para a compreensão das trajetórias e modos de vida da população de rua como um campo de concretização de um fenômeno maior que é o da exclusão social, porque nesta forma de apreensão o desvio é definido como um processo de interação entre aqueles que cometem o ato e os que reagem ao mesmo ato. $\mathrm{O}$ ato desviante 
é inconforme a uma norma prescrita por lei ou pelos costumes, e a reação dos que concordam e defendem a norma instituída resulta numa classificação do desviante como estrangeiro, marginal e/ou diferente (Becker, 1985).

Becker concentra sua atenção no processo, percurso ou trajetória desviante e não na motivação ou causa principal do ato. Desta forma o autor rejeita concepções do desvio que pressupõem que os que transgrediram uma norma constituem uma categoria homogênea na medida em que cometeram o mesmo ato desviante. Também argumenta contra as teorias que analisam o desvio a partir de uma causa subjacente ao ato desviante, situada seja na personalidade do desviante, seja nas suas condições de vida.

O que há de comum entre todos os que são classificados como desviantes é que compartilham essa qualificação, assim como a experiência de ser etiquetado como estrangeiro ao grupo. Essa identidade fundamental será o ponto de partida de minha análise. (Becker, 1985)

Considerando-se essa abordagem do desvio na análise de trajetórias da população de rua, a primeira pergunta é: qual é a norma transgredida pela população de rua? A de expor sua miséria como privação material? A de realizar em público atividades que deveriam ser exercidas nos limites da esfera privada? A de ter sido incapaz de prover suas necessidades básicas, como teto e comida, através da inserção no mundo do trabalho regular e contínuo, seja ele formal ou informal? A de tentar legitimar suas deficiências físicas (crianças, idosos e doentes em geral) e/ou mentais (alcoolismo, doentes mentais) e/ou carenciais (de medicamentos, de alimentos) para tornar-se objeto/sujeito da caridade e da assistência?

A resposta talvez seja: todas essas ou uma combinação entre elas. No entanto, há um conflito primordial entre os pontos de vista dos grupos em questão - os moradores de rua e os transeuntes - que é a privatização do espaço público.

Rua em oposição à casa, esfera privada em oposição à esfera pública. A definição de cada um dos termos da oposição é dada pelos limites estabelecidos com o outro. Há um 'muro' de convenções que delimita as atividades que devem ser exercidas em cada uma das esferas. ${ }^{276} \mathrm{O}$ que o transeunte considera como 'ações privadas realizadas em público', o transgressor pode considerar como 'satisfação das necessidades vitais'. Se este é o conflito primordial, não é de menor importância a transgressão das normas relacionadas à esfera de trabalho. $\mathrm{O}$ ato desviante dos moradores de rua está constituído por morar na rua, transgredindo um pilar da organização social que é a separação entre público e

276 "O fato de uma atividade ocorrer em particular ou em público não é, de modo algum, indiferente. Obviamente o caráter da esfera pública muda segundo as atividades que nelas são admitidas, mas, em grande parte, a natureza da própria atividade também muda" (Arendt, 1991). 
privado, e por fazer uso de modalidades de sobrevivência que são desviantes em relação aos mecanismos legítimos e convencionados de inserção social através do mundo do trabalho.

A condição de morador de rua está vinculada à ausência de um trabalho regular e contínuo que lhe permitisse suprir suas necessidades básicas no âmbito privado. Os restritos ofícios que exerce são de baixas reputação social e rentabilidade. Eventualmente, para sua sobrevivência, concorrem o estabelecimento de vínculos mais intensos com o âmbito da caridade e da assistência social. Para sobreviver através do pedido, o morador de rua deve conseguir legitimar sua condição de quem precisa ser ajudado. Deve demonstrar a sua impossibilidade de suprir de maneira convencional suas necessidades básicas, através do trabalho, e de certa forma, ser considerado como uma 'exceção à regra'. A exposição das deficiências - físicas, mentais ou carenciais - é um modo (eficaz) de legitimar o pedido. A utilização de recursos para conseguir legitimar estratégias de sobrevivência revela a existência de uma norma que foi transgredida. A norma instituída de que os indivíduos e grupos familiares devem suprir suas necessidades básicas através do trabalho regular e contínuo não leva em consideração as condições efetivas de possibilidade de seu cumprimento. A transgressão dessa prescrição moral de comportamento no mundo do trabalho tem conseqüências, na sociedade brasileira, no âmbito da cidadania.

Nem todo ato irregular cometido é percebido como uma transgressão das normas nem provoca a reação dos outros. Mas morar nas ruas é um tipo 'plenamente desviante', já que infringe a norma e é percebido como tal. Observar a existência de pessoas morando na rua é uma experiência cotidiana para os munícipes cariocas. Essa prática é considerada como desviante na medida em que, para os transeuntes, a população de rua cristaliza um modo de vida 'que não é bom para ninguém', um cotidiano 'estrangeiro', oposto à qualquer situação de vida desejada.

A existência de pessoas morando na rua não é uma novidade no Rio de Janeiro e em outros centros urbanos do País. Sua menor dimensão e sua caracterização 'tradicional' - bêbado, mendigo, louco ou migrante - ensejavam reações de caráter mais 'paroquial': 'adoção' do desafortunado pelos moradores e/ ou comerciantes da localidade, que lhe proporcionavam com certa regularidade alimentos, roupas, encaminhamentos e condução para o caso de necessidades de cuidados de saúde e mesmo atenção pessoal. Sua presença podia ser percebida com um misto de piedade, preocupação e solidariedade.

A partir do final da década de 80 as coisas mudaram de figura: seu número parece ter crescido enormemente, sua composição ficou extremamente heterogênea e o 'coitado isolado' foi substituído por grupos, familiares ou não, de adultos, crianças e adolescentes ou mistos. A sua presença passou a ser percebi- 
da como inoportuna mas, principalmente, ameaçadora. A mudança de percepção ocorreu no interior de um clima mais geral de insegurança que passou a preponderar na cidade do Rio de Janeiro no fim dos anos 80 e início dos 90 , quando surgiram novas modalidades de crime organizado (a 'indústria' dos seqüestros) e recrudesceram formas antigas (a contravenção e o tráfico de drogas), que as autoridades estaduais pareciam impotentes em conter e debelar. No interior desse sentimento coletivo preponderante a população de rua foi incorporada como 'ameaça social'. ${ }^{277}$

$\mathrm{O}$ ato desviante tem que ser observado, percebido como desviante, publicizado e transformado de 'problema' em 'questão social', para desencadear um processo que vai desde a criação das sanções até suas aplicações. A publicização do problema deve ter partido dos que se sentiram mais incomodados e/ou ameaçados - moradores e comerciantes. As reações, desde mais organizadas - como as de associações de moradores ou clubes lojistas - até as isoladas, desembocam nos órgãos públicos de segurança e assistência social. Essas pressões possibilitaram que o problema fosse observado e publicizado. ${ }^{278} \mathrm{O}$ 'problema' de existirem pessoas morando na rua, pelo aumento de sua dimensão e/ou mudança de composição, é transformado em 'questão social' com a intervenção direta da mídia, que divulga levantamentos institucionais, realiza reportagens e publica editoriais que colaboram na construção do estereótipo social 'população de rua'. Nesse processo de formação da opinião pública são mobilizados sentimentos coletivos de medo, insegurança ou mesmo solidariedade que se combinam com estes e outros sentimentos desencadeados pela experiência direta e constante de convivência e coabitação num dado espaço urbano. Esta vivência cotidiana não pode ser de forma alguma minimizada, e envolve a mobilização de sentimentos tanto nas classes médias, que se sentem incomodadas com 'as visitas que não se retiram', quanto nos trabalhadores pobres, para os quais os moradores de rua significam uma concreta e ameaçadora possibilidade de futuro.

A reação mais comum em relação aos acontecimentos nos espaços coletivos anônimos das grandes cidades é a de indiferença, ou melhor, a 'reserva', 279 de que

277 Nas observações de Luiz Antônio Machado da Silva algo semelhante teria acontecido com o jogo do bicho, que foi criminalizado 'por acaso', por meio de uma legislação que pretendia atingir os cassinos.

278

Para que um dado ato desviante seja considerado como questão social', é preciso antes de tudo divulgálo como tal, publicizá-lo como assunto de preocupação da sociedade. Para isso, Becker considera que devem existir "empreendedores da moral" cujo protótipo seria aquele que "empreende uma Cruzada para a reforma dos costumes e se sente portador de uma missão sagrada" (Becker, 1985).

Simmel denomina 'reserva' a esse aspecto subjetivo das relações sociais que envolve "não apenas a indiferença mas também uma ligeira aversão, um estranhamento e uma repulsão mútua que de repente se transforma em ódio e pavor quando de um contato mais estreito, qualquer que seja a causa" (Becker, 1985). 
nos fala Simmel - envolvendo indiferença e aversão. Becker ilustra esse sentimento mencionando uma série de fotos de pessoas que passam por um homem que jaz desmaiado numa rua movimentada de uma grande cidade. Alguns transeuntes parecem nem se dar conta da presença do homem caído e outros, que percebem, logo seguem seu caminho. Nos espaços coletivos o indivíduo não sente que os acontecimentos sejam de sua responsabilidade e, como há agentes públicos encarregados do assunto, seu papel citadino seria demandar os órgãos encarregados.

Essa é uma vivência cotidiana em vários pontos da cidade do Rio de Janeiro - pessoas passando por outras que estão dormindo, enroladas em cobertores geralmente cinzentos, ou que estão 'largadas' no chão, sem notá-las, sem parar e sem falar. Possivelmente um misto de indiferença e aversão prepondera nas relações entre os transeuntes e os moradores de rua. No entanto, o predomínio deste sentimento que apela às autoridades governamentais para a sua solução não descarta a existência de outros sentimentos, dentre os quais se destaca a solidariedade empreendida por entidades de ajuda e mesmo por transeuntes isolados. As reações dos transeuntes são variadas, perpassando a tolerância, ${ }^{280}$ a indiferença, a 'reserva', a ajuda eventual ou contínua, repulsa, rejeição, medo, desrespeito, hostilidade, pressão para dispersão ou recolhimento pelos órgãos respectivamente encarregados e agressões.

Considerando que o desvio é um processo, Becker defende que sua análise seja feita através de modelos "que levem em consideração o fato de que os modos de comportamento se desenvolvem segundo uma sucessão de fases, de mudanças de comportamento e de perspectivas do indivíduo" (Becker, 1985). Para tanto incorpora em seu estudo o conceito de carreira ${ }^{281}$ utilizado para a análise de trajetórias profissionais na própria Escola de Chicago. A carreira desviante é iniciada por um ato desviante, consciente ou não, intencionalmente transgressor ou não, e pode progredir (ou não) do ato excepcional para a sua manutenção irregular, intermitente, ocasional ou contínua. A debutância dá início a uma trajetória permeada por dilemas provocados nas interações com os não-desviantes, e a progressão na carreira depende do seu grau de envolvimento com os 'engajamentoș morais' postos pela sociedade. A passagem de um estágio a outro indicam que os diversos tipos de controle social vão perdendo sua eficácia.

O termo carreira conserva um excessivo significado profissional, mas pode ser substituído por 'percurso' ou 'trajetória', conservando as principais características da carreira desviante: não é uma modalidade de comportamento única ao longo do tempo, há mudanças de posição - modificações perceptíveis nas

280 A reação de tolerância, ainda que encerre uma certa solidariedade, envolve também uma atitude de autoisenção de responsabilidades, o que integra a naturalização da pobreza.

281 A carreira designa os fatores dos quais depende a mobilidade de uma posição a outra, tanto os fatos objetivos surgidos da estrutura social quanto as mudanças de perspectiva, as motivações e os desejos do indivíduo (Becker, 1985). 
modalidades de estratégias de sobrevivência segundo o tempo de moradia na rua. Ao longo do trabalho de campo foi possível observar alterações oriundas de fatos objetivos (eventos e circunstâncias) e subjetivos (nas formas de comportamento, perspectivas, representações de si e elaboração de justificativas). Foi possível perceber e entrar em contato com pessoas em fases diferenciadas da carreira: recente, temporário, ocasional, intermitente, contínuo; isolado, em duplas ou pertencente a um grupo, até a constituição de um gênero de vida que organiza sua identidade - como se percebe e como é percebido.

Dentre as formas de escapar dos controles sociais e engajamentos morais postos pela sociedade como obstáculos para a progressão na carreira desviante, Becker aponta a que recupera a representação do vagabundo, considerando que "aquele que não tem nem reputação a sustentar nem emprego a conservar dentro do mundo tradicional, é portanto livre para obedecer a seus impulsos" (Becker, 1985). Vários mecanismos são utilizados como controles sociais, assim como outras estratégias - clandestinidade, segredo e dissimulação - são empregadas para ocultar sua condição daqueles cuja opinião lhes é importante. Apesar do esforço, para os moradores de rua essas estratégias têm eficácia reduzida e duração transitória.

$\mathrm{Na}$ progressão da carreira o indivíduo deve ser capaz sobretudo de 'neutralizar' o controle social realizado no terreno da moralidade e das representações sociais que envolvem a construção social de um estereótipo desviante. "Se não conseguir essa neutralização, ele se autocondenará, associando-se à maioria dos membros da sociedade" (Becker, 1985). Ele deve, portanto, conseguir alterar sua sensibilidade em relação às objeções feitas pela sociedade convencional, utilizando uma série de 'técnicas', a construção de sistemas de justificativas que, no estudo de Becker, acaba por constituir uma ideologia sistemática, uma subcultura específica no interior dos grupos desviantes. O indivíduo que "mantém uma forma determinada de desvio durante muito tempo faz do desvio um gênero de vida e organiza sua identidade sobre a base de um modo de comportamento desviante" (Becker, 1985).

Analogamente é possível identificar uma trajetória de morador da rua em suas diferentes fases. ${ }^{282}$ À medida que morar nas ruas passa a ser uma alternati-

282 A trajetória de Luiz Augusto entre a primeira e última vez que o encontrei - 4 de março e 23 de abril de 1997, ficou evidenciada nas anotações do diário de campo: "Luiz Augusto é negro e mineiro, tem um sorriso bonito e simpático, parece mais velho que Roni, talvez cerca de 35-40 anos. É quase careca, mas parece como se tivesse raspado o cabelo. Está arrumado e limpo" (Copacabana, terça-feira, 4/3/97). "Luiz Augusto está vestido de calça comprida, camisa de abotoar, tem uma mochila jeans atravessada no peito e uma pochette de onde tira para me mostrar os documentos"(Copacabana, segunda-feira, 17/3/ 97). "Luís Augusto está bem diferente, sujo, com roupas que parecem ter sido ganhas, de chinelo e cheirando mal. Impressionou-me a diferença de sua aparência desde a primeira vez que o vi. Pergunteithe como andavam as coisas e ele me disse que nada bem, que tinha sido roubado perto da Catedral quando estava dormindo, que levaram a mochila com suas roupas e seus tênis"(Botafogo, Pequeninos de Jesus, quarta-feira, 23/4/97). 
va frente a uma dada dificuldade encontrada, e o tempo que permanece na rua vai aumentando, a pessoa vai aprendendo a 'se virar' e a não achar mais 'tão ruim assim' viver na rua. Torna-se efetivamente uma opção à modalidade de vida anterior e pode vir a constituir um novo gênero de vida. A partir do 'cair' na rua, há um processo de aprendizado e a aquisição de um novo vocabulário.

A trajetória de morador de rua, vida exposta 24 horas por dia ao público transeunte, envolve a utilização (com eficácia) de técnicas de neutralização ${ }^{283}$ que diminuam a influência da modalidade de percepção pública da condição de desviante sobre o seu próprio sistema de representações. Episódios vivenciados junto à população de rua permitiram coletar falas nas quais podemos observar a utilização de um conjunto de racionalizações("melhor agora do que em casa", "não é tão ruim estar na rua", "quem sabe viver, vive em qualquer lugar") que permitem que o morador de rua justifique e, de certa forma, abstraia (neutralize) sua condição de vida cotidiana e concreta.

Em alguns depoimentos os moradores de rua apresentavam-se como desprovidos da responsabilidade sobre a sua situação e totalmente impotentes frente à vida. Justificavam sua situação em expressões como "a vida foi levando", "o destino já está traçado", "foi Deus quem quis". Ou, então, dizem que entraram numa "roda viva" dentro da qual estão impotentes frente a um círculo vicioso em que a rua-que em algum momento e por algum motivo, já foi alternativa de solução - passa a ser causa do problema. Essa "roda viva" aparece também, ainda que na direção oposta, quando o morador de rua aponta uma (única) ajuda, objetiva e imediata, que the permitiria deixar de morar na rua, desde que, os acontecimentos posteriores à ajuda seguissem o desenvolvimento pré-determinado por ele. ${ }^{284}$

Outra 'técnica ${ }^{285}$ de neutralização utilizada pelos moradores de rua apregoava que a sua transgressão não provocava dano em ninguém e, portanto,

283 Becker, citando artigo sobre delinqüência de Sykes \& Matza, apresenta algumas técnicas destinadas à neutralizar a influência do respeito às leis, isto é, 'justificativas' do desvio (Sykes \& Matza, apud Becker, 1985).

284 Manuel, homem branco, alto, sem os dentes superiores da frente, vestido com calça, camisa de manga curta e tênis, limpo e arrumado, que encontrei tanto na Praça Serzedelo Corrêa quanto no café da manhã dos Pequeninos de Jesus, estava muito aflito com sua condição recente de morador de rua. Em nossas conversas ele levantou uma série de possibilidades para conseguir ganhar dinheiro e poder pagar um quarto. Manuel tinha noção dos preços e das possibilidades de lucro e apresentava um projeto viável apesar de que tudo teria que dar certo: depois de conseguir o dinheiro para comprar mercadorias no centro da cidade, ele deveria vender todas na Zona Sul para conseguir o lucro que lhe permitisse alugar um quarto e continuar comprando mercadorias (Copacabana, quarta-feira, 19/3/97).

Além dessas modalidades, Sykes \& Matza, no texto reproduzido por Becker, mencionam também: a técnica de priorizar a lealdade às normas do grupo social mais restrito ao qual pertence, em detrimento das normas mais gerais; e, nos atos de vandalismo e perseguição de minorias, a técnica de considerar que o preconceito, nas circunstâncias da ação, não é injusto, ao contrário, é uma forma justa de represália ou de castigos contra aqueles que "não ficaram no seu devido lugar" ou contra instituições escolares ou professores que não foram "corretos" (Becker, 1985). 
tratava-se de uma questão de ordem privada individual. José Eugênio, a quem encontrei junto com os catadores da rua Sorocaba mas que não pertencia ao grupo mais estável do local, contou que estava no Bairro Peixoto, quando um guarda o acordara chutando-o dizendo que ali não poderia ficar. Ele argumentava, dizendo que não estava perturbando ninguém. ${ }^{286}$ Também o guarda municipal da Praça Serzedelo Corrêa, em Copacabana, mencionou que ao tentar que as pessoas se retirassem do entorno da praça, alguns reagiam: "aí, meu irmão, nós não estamos te atrapalhando em nada". ${ }^{287}$ Marcelo dizia que nunca fora recolhido porque raramente dormia em um lugar que pudesse incomodar os outros, "que alguém ligue reclamando". ${ }^{288}$ André, catador de lixo, ia além dizendo que os moradores (com teto, da rua Sorocaba) já estavam (tão) acostumados com eles (catadores), que os ajudavam e que até reclamavam se quisessem levá-los porque eles "dão jeito na rua, põe ordem" no lugar. ${ }^{289}$

Dentre as modalidades de abstração e justificativa encontra-se também a concentração do discurso em referências a um passado glorioso, a grandes feitos ou façanhas em que uma avaliação do tempo presente não tem lugar. José Eugênio tinha um discurso desse estilo: "ele afirmava alto que teve de tudo, onze apartamentos alugados, caminhão, carreta (...) que já foi muito poderoso". ${ }^{290} \mathrm{Na}$ entrevista conjunta de Miguel e Cícero/Wellington, os dois apontaram a utilização freqüente do exagero, das 'bravatas' e das mentiras pelos moradores de rua. E Márcia falava do seu cotidiano: "acorda, lava o rosto, consegue água no quiosque, se tiver dinheiro vai tomar café, depois fica por aí, contando mentiras junto com os outros". 291

A última etapa de uma carreira desviante consiste no ingresso em um grupo no qual "compartilha um mesmo destino e os mesmos problemas". O pertencimento a um grupo como tal cristaliza a identidade desviante, isto é,

um conjunto de idéias e pontos de vista sobre o mundo social e sobre a maneira de a ele adaptar-se, assim como um conjunto de atividades rotineiras baseadas nesses pontos de vista. (...) Entrando num grupo tem mais chances que antes de prosseguir nessa via: de um lado aprende como evitar as dificuldades, de outro lado, adquire um sistema de autojustificação que $o$ incite a perseverar. (Becker, 1985)

286. Diário de campo, Botafogo, segunda-feira, 3/3/97.

287 Diário de campo, Copacabana, quinta-feira, 6/2/97.

288 Diário de campo, Botafogo, segunda-feira, 21/4/97.

289 Diário de campo, Botafogo, segunda-feira, 3/3/97.

290 Diário de campo, Botafogo, segunda-feira, 3/3/97.

291 Diário de campo, Copacabana, sábado, 19/4/97. 
Os moradores de rua em suas modalidades de agrupamento constituem grupos desviantes similares, compartilhando uma existência em comum e um conjunto organizado de significados. Entretanto, no caso dos músicos de jazz estudados por Becker, com um gênero de vida suficientemente bizarro frente aos padrões convencionais para ser classificado como 'diferente', o ponto de partida da diferença era um 'dom'. Os músicos consideravam-se portadores de um atributo que os distinguia favoravelmente dos 'quadrados' (que compõem seu público e seus empregadores) (Becker, 1985), ou seja, numa representação de exterioridade positiva. $\mathrm{Na}$ trajetória dos moradores de rua a diferença é dada por uma falta, uma ausência, uma carência que os distingue negativamente em relação aos transeuntes. $\mathrm{O}$ isolamento e auto-segregação dos moradores de rua não pode ultrapassar certos limites de segurança e de sobrevivência. Em alguns casos não pode desvincular-se totalmente dos grupos e da rede de ajuda, sob o risco de não conseguir manter-se vivo. A auto-segregação se desenvolve, as inter-relações diretas são restringidas ao máximo, o sentimento de hostilidade está presente e o estatuto de exterioridade é explicitado (e reforçado) num vocabulário próprio ${ }^{292}$ mas, na maioria das vezes, sob o signo da dependência.

Esses mecanismos de ordem subjetiva que os moradores de rua lançam mão (assim como outros grupos desviantes e delinqüentes) para diminuir sua sensibilidade diante dos estereótipos sociais sobre a sua condição de vida não podem mascarar a interferência dos fatos objetivos, que pode ser sintetizada nas condições de (im)possibilidade do cumprimento da norma pelo morador de rua. Em que medida, tomada a decisão de não morar mais nas ruas, o indivíduo tem condições de suprir-se de escolaridade e qualificação, criar o 'fundo de consumo' para sua reprodução, enfrentar os mecanismos de absorção no mercado de trabalho e conseguir satisfazer suas necessidades básicas dentre as quais, especialmente, um teto doméstico?

A partir da transgressão da norma, cometido o ato desviante e percebido como tal, o transgressor é 'etiquetado' e sancionado. A 'etiqueta' lhe confere um estatuto de estrangeiro (outsider) ao grupo.

Ser considerado e estigmatizado como desviante tem conseqüências importantes sobre a participação posterior na vida social e sobre a evolução da auto-imagem do indivíduo. A consequêencia principal é uma mudança de identidade do indivíduo aos olhos dos outros. Em razão da falta cometida e do caráter flagrante desta, ele adquire um novo estatuto. Descobre-se uma personalidade diferente: ele será etiquetado e tratado como tal.(Becker, 1985)

292 Vide o glossário de três páginas publicado em Sebes/SP, 1992. 
A condição de desviante é "uma categoria de estatuto principal”, preponderando nas interações sociais sobre os vários outros atributos de um mesmo indivíduo (raça, gênero, profissão etc.). "A identidade desviante comanda as outras identificações" (Becker, 1985). Esse estatuto, além do significado simbólico mais geral (ter transgredido uma 'norma'), comporta um certo número de conotações que atribuem a todos os etiquetados características acessórias presumidas como associadas automaticamente à característica desviante mais geral. Toda etiqueta é homogeneizadora, negligenciando as diferentes trajetórias individuais, e a personalidade que emerge é uma representação social daquela modalidade de desvio.

No caso da população de rua, ao estatuto de 'estrangeiro' - atribuído devido ao fato de viver nas vias públicas e não ter uma inserção social legitimada no mundo do trabalho - estão associadas, em diferentes graus, as seguintes características acessórias: pobreza, sujeira, alcoolismo, utilização de meios inescrupulosos ou mesmo ilegais de sobrevivência como o roubo e o tráfico de drogas ('avião'), preguiça e/ou distúrbio de personalidade. Em relação a boa parte do conjunto de características acessórias atribuídas à 'personalidade' morador de rua, este é falsamente acusado, mas isso não impede que através dos estereótipos seja lançado na 'vala comum' que homogeneiza nesse perfil a diversidade de trajetórias.

"A maneira como os desviantes são tratados equivale a lhes recusar os meios comuns de cumprir as atividades rotineiras da vida cotidiana" (Becker, 1985). No caso da população de rua a falta de acesso às atividades rotineiras da vida cotidiana é o próprio elemento de configuração de sua trajetória. Há que considerar-se também que um indivíduo dedicado a sobreviver na rua tem seus horários de trabalho e alimentação determinados pelos transeuntes (para guardadores de carros, catadores de lixo) ou pelas entidades de ajuda.

Quais são as sanções impostas aos moradores de rua e que 'corpo especializado' as impõe? Como são percebidas as normas pelos moradores de rua ?

Vadiagem, ociosidade e mendicância foram criminalizados no Código Penal aprovado na época do Império e vigente no início do século $\mathrm{XX}^{293}$ mas atualmente deixaram de ser crimes. No entanto, mesmo que a norma não se apresente mais editada formalmente em lei, por referir-se a pilares de sustentação da sociabilidade (a separação entre os espaços público e privado e a inser-

293 "Considerando como crimes policiais a prática da vadiagem e da mendicância, a polícia usava e abusava do livre-arbítrio, prendendo freqüentemente aqueles que perambulavam pelos espaços públicos. Eram considerados vadios todos aqueles que não possuíam ocupação honesta e útil de que pudessem subsistir. A persistência em tal estado, após a advertência pelo Juiz de Paz, implicava pena de prisão com trabalho por oito a vinte e quatro dias. Quanto aos mendigos, o fato de mendigar tendo supostamente condições para trabalhar implicava a prisão, simples ou com trabalho" (Valladares, 1991). 
ção por meio do trabalho), mantém-se revestida de forte autoridade. O caráter de 'norma-pilar' lhe confere a característica de estar difusa em todos os domínios da vida social e de poder também ser difusamente sancionada, de maneira formal ou informal.

A execução da sanção imposta à transgressão, dependendo do âmbito das relações sociais, pode ter como corpo especializado desde agentes públicos encarregados da segurança e/ou da assistência social, investidos de autoridade regulamentada, passando por regras de comportamento e ação exigidos pelas entidades assistenciais para freqüentar e utilizar os serviços, até os acordos informais com os transeuntes de convivência regular, isto é, moradores com teto, comerciários e comerciantes, fregueses e empregados de bares e restaurantes, garis e pessoas que transitam com mais regularidade pelo local - e, ainda, pode ser atribuição também de todo e qualquer transeunte que compartilhe o espaço público.

Tem preponderado uma jurisprudência restritiva em relação aos espaços públicos como praças e jardins, que nos últimos anos tornaram-se locais fechados, com grades e com regras de circulação e utilização. ${ }^{294}$ Com a criação da Guarda Municipal aumentou, por proximidade, a eficiência da repressão em relação aos demais órgãos de segurança como a polícia civil ou militar. Não é à toa que nas representações da população de rua o policial é bem visto, não atrapalha, não bate, não interfere - só em 'casos suspeitos'295 - enquanto os Guardas Municipais são vistos por Cícero como os "que mais persegue; pegaram uma pessoa assim de rua, bateram tanto nele que quebrou o maxilar dele". ${ }^{296}$ "A polícia, se vir fazendo alguma coisa falam, né?, agora aqueles guardinhas municipal são um cão, né? eles são fogo"297 - diz Miguel. Vanda e Márcia contavam que nas operações de recolhimento os guardas municipais são encarregados de impedir a fuga: "se correr pra fugir eles vão atrás e batem", e que no dia a dia quem perturba são os 'guardas de bicicleta' (guardas municipais da orla). ${ }^{298}$

No depoimento do Guarda Municipal da praça Serzedelo Corrêa foi possível observar uma avaliação pessoal do conteúdo da regulamentação e a

294 Na praça Serzedelo Correia há placas com as regras de utilização: horário 6h às $19 \mathrm{~h}$; cachorro com coleira, somente travessia; proibido andar de bicicleta, exceto menores de 10 anos; proibida a passagem de carrinhos com latas e garrafas; proibida a passagem e a permanência de vendedores e ambulantes.

Os casos podem tornar-se 'suspeitos' de várias formas: comportamento inadequado, locais freqüentados ou possibilidade de envolvimento com tráfico de drogas. Na entrevista, Miguel declarou: "policial, se tu tiver aqui na rua, ai ele te der geral, ele abriu a bolsa vai saber na hora que tu mora na rua, cobertor, colher, pasta de dente, sabonete, essas coisas, ele vai saber, e eles não faz nada, não mexem, só se tiver fazendo coisa errada". Diário de campo, Botafogo, segunda-feira, 14/4/97.

Diário de campo, Botafogo, segunda-feira, 14/4/97.

Diário de campo, Botafogo, segunda-feira, 14/4/97.

Diário de campo, Copacabana, sábado, 12/4/97. 
seletividade do agente encarregado na aplicação das normas. Ele dizia que se um 'mendigo' entrar na praça, sentar no banco tranqüilamente, não fizer arruaça nem ameaçar o patrimônio ele não podia fazer nada, era "um cidadão como qualquer outro". As pessoas reclamavam com ele dizendo que "o mendigo está lá sentado, fedendo", mas ele respondia que não havia nada que o impedisse de ficar ali desde que não causasse problemas: "está no direito dele de ir e vir". Mas, "se o sujeito se fizer de malandro, cheio de gíria e cheio de pose" - faz com o corpo o trejeito - ele mandava sair, ameaçava usar a sua autoridade e de pedir reforços ${ }^{299}$

No duplo sentido de outsider importa também como os 'etiquetados' percebem as normas. Essas percepções variavam desde considerá-las justificadas e legítimas, passando por ambivalências, até interpretá-las como tão 'estrangeiras' ao seu universo que careciam de respeitabilidade e legitimidade. Becker exemplifica da seguinte forma: o infrator de trânsito tem uma relação de conformidade à norma pois, admitindo ou não a transgressão, não questiona a legitimidade da existência de regras de trânsito. Os alcoólicos estabelecem uma relação de ambivalência com a norma, pois reconhecem que a ingestão crônica de álcool é nefasta mas consideram que aqueles que os julgam não os compreendem. Os homossexuais, os toxicômanos e mesmo os músicos de jazz, por sua vez, recusam qualquer legitimidade à norma e elaboram uma ideologia sistemática explicativa de por que eles estão certos e aqueles que os desaprovam e punem estão errados. Essa ideologia sistemática que informa um certo gênero de vida é elaborada através de racionalizações e justificativas, as mencionadas 'técnicas de neutralização', criando um ponto de vista 'emancipado' em relação às normas morais da sociedade convencional (Becker, 1985).

Os moradores de rua com quem entramos em contato manifestaram-se diferentemente em relação à respeitabilidade e legitimidade das sanções impostas segundo os agentes encarregados de execução. As ações de dispersão e recolhimento realizadas por orientação da prefeitura e pressões dos munícipes respondem de maneira paliativa a uma problemática social evidenciada no uso do espaço urbano de convivência. Entre os moradores de rua foi unânime considerá-las sem qualquer legitimidade, respeitadas apenas pela imposição da autoridade, ameaça e concretização do uso da força física. A aplicação das normas era vista como ilegítima porque não redundava em qualquer conseqüência sobre suas condições de vida. Os moradores de rua, ainda que passivamente, questionavam não o conteúdo do regulamento e sim a sua própria existência, já que, segundo eles, não estavam incomodando ninguém

Em relação às normas de comportamento e ação impostas por entidades de assistência social, o feixe de reação dos moradores de rua comportou varia-

299 Diário de campo, Copacabana, quinta-feira, 6/2/97. 
das reações: a conformidade às normas com estabelecimento de vínculos, geralmente de caráter religioso; a conformidade sem constituição de vínculos sociais numa relação instrumental ou pragmática; uma conformidade de menor intensidade com a elaboração de queixas e denúncias, até a crítica severa; e, ainda, a reação violenta com a destruição dos locais de serviços. Quanto aos transeuntes de convivência, os acordos informais de convivência dependiam do grau de fixação do morador de rua naquele espaço e dos tipos de relações estabelecidas, que podem variar entre um vínculo de trabalho e rendimentos, uma relação de vizinhança espacial, um suposto elo de proteção, ou a rejeição também em graus variados.

\section{mOVImenTo: a eternidade do transitórıo}

Uma característica freqüentemente assinalada como integrando o perfil dos moradores de rua é o seu nomadismo, ou seja, o deslocamento contínuo pelos espaços públicos da cidade. Embora esse movimento permanente seja efetivamente observável, é importante refutar as análises que situam a característica como intrínseca à 'natureza' do morador de rua, isto é, como elemento integrante de sua personalidade, o qual, inclusive, funcionaria como um elemento motriz para sua 'opção' de residir nas ruas. A mobilidade da população de rua é parte da caracterização do fenômeno e, portanto, condicionada às relações sociais estabelecidas entre os habitantes das ruas e os demais transeuntes.

Como etapa civilizatória o nomadismo é anterior à fixação do homem ao solo. "Nossa existência primária é a de caçadores, coletores e pastores; um passado de nomadismo" (Enzensberger, 1995). E, mesmo após tantos séculos de sedentarização, continuam ocorrendo movimentos contínuos e incessantes de grupos humanos pelo planeta.

$\mathrm{Na}$ análise dos movimentos migratórios alguns elementos aparecem como constantes: os indivíduos mais capazes, mais dinâmicos, mais decididos são os que optam por migrar e o fazem sempre na perspectiva de uma 'vida melhor', qualquer que seja o significado dessa expectativa. Dessa forma, a emigração "institui um processo de seleção que não é favorável para o país (ou local) natal". Uma segunda característica seria que toda migração leva a conflitos, instituindo a figura do estrangeiro, do estranho ao local: "a defesa dos interesses locais e a xenofobia são constantes antropológicas e, para mantê-los sob controle, para evitar banhos de sangue (...) as sociedades antigas inventaram os tabus e os rituais da hospitalidade. Esses cuidados, porém, não revogam o status do estrangeiro. Pelo contrário: eles o fixam". Um terceiro elemento assinalado 
é que a reação ao estrangeiro está relacionada com suas posses: "ninguém questiona a liberdade de movimento dos ricos e os estrangeiros são mais estrangeiros se forem pobres" (Enzensberger, 1995).

A reação aos movimentos migratórios é maior quando realizados por pobres, e a pobreza está associada ao movimento: como reação - mais acentuada nos mais jovens - às vulnerabilidades múltiplas e associadas; na busca de soluções; como recusa em aceitar passivamente as perspectivas que circundam suas vidas em família e no bairro (Alvim, 1995). De forma tal que é verificado, particularmente no gênero masculino, um 'discurso de mobilidade' (Agier, 1990), relacionado à pobreza das classes trabalhadoras, anterior à moradia nas ruas e consubstanciado nas expressões 'ir à luta', 'correr atrás' e 'ter que se virar'. O transitar de crianças e adolescentes nas ruas, organizados em grupos, com lideranças constituídas, é considerado por Silva \& Milito uma "verdadeira insurreição infanto-juvenil" contra as condições de vida que a sociedade lhes impõe associada ao elementos próprios que marcam a criação de uma identidade adolescente. No entender dos autores trata-se de um "movimento coletivo, socializado no sentido de que seus pares adultos (...) ou toleram, ou entendem, ou incentivam, ou se resignam, ou naturalizam tal movimento de recusa aos espaços da miséria e da violência" (Silva \& Milito, 1995).

A associação da pobreza com o movimento é analisada por Da Matta no 'mito de Malasartes', que

também pode ser tomado como o mito do trabalhador brasileiro, como a saga daquele que tem que estar sempre buscando algo que não possui; sempre - como eles mesmos dizem - em busca do trabalho e do patrão, sobretudo do 'bom patrão' que os ancore definitivamente na estrutura social. Numa palavra, quem é pobre precisa 'ganhar a vida'. (Da Matta, 1990)

Entretanto, a âncora na estrutura social por meio do trabalho e do 'bom patrão' não é de fácil obtenção, na medida em que o 'nomadismo ocupacional', o trânsito entre o assalariamento com carteira de trabalho, o mercado informal e o desemprego e, em certos casos (jovens e mulheres) a inatividade, configuram traços característicos da inserção dos trabalhadores de baixa qualificação.

Aos elementos estruturais e tradicionais do fluxo contínuo de grupos sociais pauperizados, Buarque adiciona outros mais contemporâneos, gerando neste final de século o que denomina de modernômades:

centenas de milhões de nômades perambulando por estradas, entre ruas, cidades e mesmo continentes, produzidos e reproduzidos pela modernidade. O padrão excludente de desenvolvimento econômico e social, restrito a apenas uma parte da população, é um elemento gerador de migração forçada e de um movimento incessante pois quando chegam aos locais continuarão sendo nômades, agora como habitantes das ruas. (Buarque, in Bursztyn \& Araújo, 1997) 
O nomadismo nas ruas chega a ser caracterizado como especificidade de um modo (andarilho) de vida, ou seja, fazendo da mobilidade não apenas um período transitório, como ocorre com a migração, mas uma forma de vida, mantida ao longo dos anos e através das gerações (Magni, 1997). Magni argumenta que o nomadismo como modo de vida da população de rua possibilita uma identificação positiva do grupo social, opondo-se às caracterizações com base nas negatividades semânticas (sem-teto, sans domicile fixe - SDF) que os apresenta a partir da ausência ou da carência em relação a algo que se apresenta como um valor social básico - neste caso, o lar, a residência (Magni, 1995). Assim, as pessoas que vivem nas ruas seriam caracterizadas como um 'povo cigano', em que o nomadismo faria parte de uma cultura com tradições e costumes próprios, transmitidos de geração em geração, parcial ou integralmente imunes aos valores prevalentes nos lugares por onde transitam. Embora o conceito de 'modo de vida' permita articular "objetividade e subjetividade, condições de vida e representações simbólicas, estrutura e sujeito" (Lobo, 1992), é mister ressaltar que, no caso dos moradores de rua, a imposição dessa maneira de viver 'andando por aí', a pequena autonomia e o isolamento do sujeito falam contra o nomadismo ser propriamente um modo de vida.

Os elementos que configuram o movimento da população de rua em oposição aos demais grupos sociais são: a circulação permanente ao invés da fixação, o provisório em vez do permanente, o transitório e o efêmero ao contrário da inserção e do pertencimento, o acaso ao invés do regulado e conhecido, a intermitência antepondo-se ao contínuo e o eterno presente em contraposição à capacidade de sonhar, às perspectivas de futuro.

Moram nas ruas mas aí não encontram um lugar fixo e próprio. Para sobreviver - na busca de alimentação, proteção contra as intempéries e fuga da repressão institucionalizada ou não - devem circular pelos espaços. "Perambulando pelas ruas, descobrem que são capazes de circular nesse mundo, embora a ele não pertençam" (Bursztyn \& Araújo, 1997). A rua não oferece como espaço, nem tampouco os grupos que nela se constituem, uma unidade de pertencimento. São seres desenraizados: perderam suas raízes geográficas, familiares e culturais, mesmo que habitem nas ruas do mesmo local em que nasceram, e a nova sociabilidade que constituem nas vias públicas, tendo como característica a fluidez, a inconstância de pessoas e lugares, não possibilitam que sejam criados novos elementos de fixação. Estabelecem uma certa rotina diária de obtenção de rendimentos ou de alimentação, porém esta pode ser irregular e intermitente na medida em que dependem de normas e regras que não controlam e sobre as quais não podem interferir. O espaço da rua é, por si só, um "espaço de mobilidade" (Sposati, 1995), local de trânsito, movimento e circulação de pedestres e veículos. Nas ruas tudo se move continuamente e o morador de rua, em seu caminhar permanente, não faz senão adaptar-se ao seu habitat. 
A rua impõe horários: quem nela habita deve acordar cedo, sair das marquises e das portas de lojas ou prédios residenciais, independentemente das intempéries, de sua condição ou disposição. As lanchonetes e restaurantes ou a oferta assistencial estabelecem o horário da alimentação. Quando acumula pertences aumenta sua visibilidade e desencadeia a repressão. É recolhido ou deve sair do lugar. Para sobreviver, precisa circular e essa é uma imposição que o espaço das ruas estabelece sobre o cotidiano dos que nelas habitam.

Apesar de ter que se movimentar continuamente, o morador de rua tende a estabelecer um território de circulação. Ou seja, é itinerante mas dentro de um espaço delimitado. "Ele vive circunscrito a um habitat por ele definido que pode ser até ao longo de uma rua ou em torno de um bairro, praça ou quarteirão" (Simões Jr., 1992). A territorialidade dos grupos de crianças e adolescentes nas ruas é um elemento tão característico que "tentar uma tipologia dos meninos depende de uma topologia” (Silva \& Milito, 1995). Uma das regras básicas do agrupamento é a observância da territorialidade, o controle do espaço, a delimitação de percurso; a chegada de estranhos (estrangeiros) é alertada com a expressão ‘tem alemão no pedaço'. A tipologia topológica parece identificar perfis diferenciados de grupos organizados em torno de territórios, com diferenças em suas auto-representações e atitudes na rua, entre meninos de rua de várias cidades ou entre localidades de uma mesma cidade (Silva \& Milito, 1995).

Os depoimentos revelaram a territorialização da moradia, como no caso de Dalton, que dizia que a marquise podia variar mas sempre era em Botafogo; ou Miguel, que passava o dia entre Botafogo e Copacabana, onde 'garimpava' o lixo e conseguia alimentação, mas dormia em Ipanema, num "lugar calmo, bom de se ficar": era um canteiro perto de um edifício, onde ele afastava os vasos de plantas e fazia um "quadradinho" que ficava "quentinho", não chovia e era seguro: "não mexem com a gente". 300

A sobrevivência fisiológica, a obtenção de ajudas e rendimentos, a estabilidade de composição e a permanência no espaço dos agrupamentos de moradores de rua estão condicionados, primordialmente, pelo tipo de espaço urbano ocupado. Os grupos, instáveis em sua composição, tendem a uma estabilidade de localização, constituindo pontos de moradia e sobrevivência. Em todas as cidades os grupos se localizam ao redor de centros de consumo, distribuição esta que, em Brasília, adquire configurações urbanísticas bem demarcadas: área de supermercados, área de bancos, área de clínicas. Nas demais cidades - Rio de Janeiro, São Paulo e Porto Alegre - o local preferido é o centro, por oferecer as condições de sobrevivência e também porque, ficando deserto à noite, confere ao grupo uma privacidade doméstica. As entidades de ajuda que fornecem ali-

300 Diário de campo, Botafogo, quarta-feira, 9/4/97. 
mentação e auxílios diversos constituem importantes pólos de atração de agrupamentos, identificados pelo horário em que se encontram. Pontos fixos e estabelecidos podem ser modificados segundo uma ação mais intensa dos órgãos públicos mas, sem dúvida, os locais mais propícios para dormir e viver na rua acabam sendo (re)ocupados por grupos, constituindo-se em pontos tradicionais de ocupação.

A hospitalidade do espaço urbano carioca foi substancialmente modificada nas últimas décadas, prevalecendo um processo em que o espaço privado foi 'fortificado' nos condomínios fechados e o espaço público foi 'selecionado' com o gradeamento das praças. Segundo Neves, esse processo concentrou os desabrigados em espaços delimitados de obtenção de rendimentos e de sociabilidade, aumentando a sua visibilidade e, ao mesmo tempo, permitindo que eles desenvolvessem práticas de reconhecimento de sua existência, estimulados pela vida em grupo (Neves, 1995a).

A visibilidade, naturalmente, aumenta com a limitação dos espaços, com a magnitude numérica e com a tendência à fixação do grupo. $O$ aumento da visibilidade dos grupos tem correlação positiva com a intensidade da repressão. O agrupamento é um critério institucional para o recolhimento: a Fundação Leão XIII não recolhe se andar sozinho, somente se se formarem grupos: "se tiver com galera, com patota, a gente leva" (Martins, A.L., 1993).

O movimento constante e o isolamento tendem a diminuir a visibilidade da ocupação e habitação do espaço público nas grandes cidades. Nesse sentido são os depoimentos dos que adotam o isolamento como forma de evitar conflitos, seja entre moradores de rua, seja com transeuntes, seja com as instituições. Itinerância e fixação se intercalam no cotidiano dos moradores de rua, variando segundo as circunstâncias. Alguns fatores interferem propiciando a fixação, como a sombra de uma árvore ou uma marquise que proteja mais, a complacência e a compaixão dos transeuntes, trabalhadores e moradores com teto do local, a baixa visibilidade de locais que possibilitem o acúmulo de pertences e a proximidade da rede de sobrevivência e de acesso à água. Alguns locais sempre estavam ocupados, ainda que nem sempre pelas mesmas pessoas. Em outros espaços a presença de pessoas tinha estreita dependência do horário e do dia da semana.

Por outro lado, os elementos que favorecem a itinerância são as condições climáticas, a realização de eventos (numa noite de jogo de futebol a população de rua de Botafogo diminuiu sensivelmente, devido ao deslocamento das pessoas para as proximidades do Maracanã, onde podiam encontrar fartura de latas), o aumento da visibilidade do local (a conclusão de obras públicas e a retirada do entulho), os dias da semana e o horário (exemplos típicos são as igrejas nos domingos e as agências bancárias em dias de semana). A itinerância 
é condicionada pelos horários estabelecidos para distribuição de comida e outras doações pelas instituições assistenciais, assim como por fatores relacionados com as possibilidades de trabalho e rendimentos através da coleta do lixo, no caso, as relações estabelecidas com porteiros e vigias para acesso às 'fontes', o horário de passagem do caminhão da limpeza urbana e o horário de funcionamento dos depósitos. A fixação depende de que não haja reclamações (porteiros, moradores, comerciantes) e, por vezes, ocorrem mudanças de locais por outros interesses (amizades ou comida mais próxima).

Foi possível observar locais típicos de pedido de esmola perto de bancos (agências ou caixas 24 horas) ou de supermercados. Esses pontos eram ocupados sempre pelas mesmas pessoas, em geral idosos ou deficientes físicos, cujas marcas do infortúnio eram visíveis e, portanto, garantiam a legitimidade do pedido. A escolha desses lugares parece acontecer devido não só ao movimento de pessoas, como também ao 'apelo à consciência' que propiciam. A transitoriedade da fixação era visível pelos vestígios (lixo, papelão, sacolas, restos de comida e mesmo colchões e lençóis), que indicavam a passagem pelo local e a possibilidade de um retorno. Foi possível observar tanto moradores de rua mais fixos, como os catadores da rua Sorocaba e Solange, que se instalou na calçada da rua Nelson Mandela, quanto outros que viviam em trânsito. Dentre estes últimos existiam dois subgrupos: os que percorriam itinerários fixos e repetidos diariamente e os que andavam segundo as circunstâncias.

Alguns dos que se locomovem pela cidade conseguem fazê-lo andando de ônibus 'de calote'; a imensa maioria, porém, percorre longas distâncias a pé, atravessa vários bairros caminhando. É difícil apreender os detalhes de quem se move continuamente, mas também o movimento (junto com a aparência) denuncia a condição de ser integrante da população de rua.

O caminhar dos moradores de rua mistura as duas formas básicas de deslocamento assinaladas por Da Matta: o do mundo cotidiano e o do mundo ritual. $\mathrm{Na}$ marcha do cotidiano os momentos importantes são o da partida e o da chegada, tendo pequena importância a passagem entre um e outro. No mundo ritual, ao contrário, é a marcha, o processo de deslocamento em si, que se torna importante. Enquanto o caminhar cotidiano é funcional, racional e tem um objetivo específico, na marcha ritual "o alvo e a jornada se tornam mais ou menos equivalentes"; "o básico é como se marcha, como se vai, e nunca onde se chega" (Da Matta, 1990).

Para os moradores de rua, o caminhar cotidiano tem objetivos precisos, e o ponto de chegada é não apenas importante mas, por vezes, até vital. Entretanto, há também um caminhar ritual, em que o importante é estar em movimento, no deslocamento que ocupa sua jornada, uma maneira de passar o tempo e evitar conflitos, até mesmo porque não têm onde permanecer. Quando per- 
guntei a Luiz Augusto como tinha passado a semana, ele me respondeu: “ andando". ${ }^{301}$ Rodrigo me contou que "anda por aí, roda tudo por aî" 302 Dalton dizia que "não gosta de ficar parado, que gosta de ficar andando". 303 E Cícero argumentava: " eu sempre gostei de andar, sabe?, eu não consigo ficar parado num lugar. Se eu pudesse a minha vida eu vivia viajando direto, eu ia conhecer o mundo todo". Quando the perguntei como era o seu cotidiano me respondeu:

eu acordo, ai nós vai catar, boje catemos aqui em Copacabana, amanhã no Humaitá, ai depois vende os negócio, vai pro cemitério tomar banbo, aí pronto, passa o dia, não tem mais o que fazer, (fico) andando, assim, andando... sem ter pra onde ir. ${ }^{304}$

Se a itinerância e a fixação são determinadas pelas circunstâncias, ainda que uma certa rotina possa estar presente, o cotidiano do morador de rua está fora de seu controle, fica ao sabor do acaso. O imprevisível, o inconstante, o incontrolável, o inusitado configuram suas trajetórias nas ruas. Vivem num espaço que é um 'território de ninguém'. Não encontram um lugar onde fixar-se e movem-se continuamente. Assemelham-se mais aos apátridas do que aos estrangeiros, pois estes últimos têm um lugar no mundo, embora não seja aquele em que estão, enquanto os apátridas são os 'sem lugar no mundo', e conseqüentemente tampouco dispõem de qualquer estatuto legal, ou seja, não têm existência jurídica. ${ }^{305}$ Embora os moradores de rua não sejam apátridas no sentido exato do termo, assemelham-se a estes por instalaram-se no 'território da infracidadania', isto é, por se situarem à margem da lei e dos direitos, de cuja existência formal não conseguem usufruir. Quando os homens são privados de seus direitos "bênção e ruínas lhes serão dados ao sabor do acaso e sem qualquer relação com o que fazem, fizeram ou venham a fazer" (Arendt, 1989).

Vivendo em público mas sem participar do espaço público, acabam por não pertencer a nenhuma comunidade política e permanecem à margem da cidadania, que constitui o primeiro direito humano, o 'direito a ter direitos'. $\mathrm{E}$, como nos lembra Arendt, os direitos humanos - definidos como 'inalienáveis, irredutíveis e indeduzíveis de outros direitos e leis', porque eram destinados a ser independentes de todos os governos - passam a ser inexistentes quando não há nenhuma autoridade legal para protegê-los e nenhuma instituição dis-

301 Diário de campo, Botafogo, quinta-feira, 3/4/97.

302 Diário de campo, Botafogo, domingo, 2/3/97.

303 Diário de campo, Botafogo, domingo, 9/3/97.

304 Diário de campo, Copacabana, quinta-feira, 17/4/97.

305 "A partir da $1^{a}$ Guerra Mundial surgiram compactos grupos humanos que não eram bem-vindos e não podiam ser assimilados em parte alguma. Uma vez fora do país de origem, permaneciam sem lar; quando deixavam o seu Estado, tornavam-se apátridas; quando perdiam os seus direitos humanos, perdiam todos os direitos: eram o refugo da terra" (Arendt, 1989). 
posta a garanti-los. Cria-se uma situação em que grupos humanos não têm direito algum e apenas como transgressores da lei, como criminosos, poderiam voltar a ser cidadãos completos, ou seja, pessoas consideradas (e protegidas) pela lei (Arendt, 1989).

A rua é o espaço do imprevisível, da insegurança e da vulnerabilidade, do perigo constante que espreita. Por isso, "as situações exigem presteza, as reações aos estímulos têm que ser muito rápidas" (Silva \& Milito, 1995). Nesse espaço há uma temporalidade própria, a do "eterno presente", a ausência de perspectivas de futuro. A somatória de experiências fragmentadas, o desenraizamento de suas origens e trajetórias familiares, as limitações concretas e crescentes que impedem que ultrapassem a muralha da desvinculação fazem com que a idéia de um futuro fique cada vez mais distante, algo doloroso de pensar posto que inatingível. A capacidade de sonhar é o que permite distinguir o movimento do migrante daquele da população de rua. "O sonho de encontrar as condições para viver com mais dignidade é o elemento energizador da errância que nutre os processos migratórios em nosso país. Se estou certa, o homem da rua seria o homem que deixou de sonhar" (D’Incao, 1995).

O migrante se move continuamente, pois está à procura de um futuro 'melhor', enquanto a população de rua perdeu sua habilidade de sonhar ou essa capacidade está envolta na névoa da embriaguez, que a faz acreditar ser possível o que a realidade lhe mostra dura e cruamente ser inatingível. "Se não há futuro a ser construído, também não tem sentido a criação de projetos. Ficam os indivíduos com os devaneios, os sonhos, as façanhas do fanfarrão, a alegria descompromissada do bufão" (Neves, 1995). As perspectivas de futuro estão bloqueadas e a vida está limitada a conseguir sobreviver. Limitados a conseguir permanecer com vida, torna-se permanente o ato de morrer. 